https://doi.org/10.48009/1_iis_2005_282-288

\title{
AN INTEGRATED FRAMEWORK FOR AN INFORMATION SYSTEMS PROGRAM ASSESSMENT
}

\author{
Monica C. Holmes, Central Michigan University, monica.c.holmes@ cmich.edu \\ Nancy Csapo, Central Michigan University, nancy.csapo@cmich.edu
}

\begin{abstract}
The assessment movement in education has brought about mandates for educational institutions to develop, implement, and continuously evaluate assessment plans. The purpose of this paper is to present the application of a well-recognized assessment process to an undergraduate information systems (IS) program. Key elements and considerations for an effective assessment plan will be discussed, including the importance of feedback and student self-assessment, the use of non-traditional assessment methods specifically for information systems (IS) courses, and specific assessment methods tied to course goals and program objectives.
\end{abstract}

Keywords: Assessment, assessment plan, learner-centered, IS program assessment

\section{INTRODUCTION}

The assessment movement in education has brought about mandates for educational institutions to develop and implement assessment plans. National accrediting agencies also mandate requirements for assessment and specify assessment plans [7]. This assessment movement also includes distance learning, online colleges and universities and reflects the current view in higher education to focus on student learning (student-centered approach) rather than teaching $[2,6]$.

Any Information Systems (IS) program of study needs to include a carefully designed assessment plan that reflects the following elements: (i) a thorough understanding of how students learn; (ii) a variety of measures used to assess student learning and provide feedback; and (iii) a course of action or plan for implementing the assessment of learning throughout individual courses within the program. How well we assess student learning in each individual course contributes to our understanding of the quality of student learning at the end of a program. This assessment process goes beyond the teaching of technical skills to the students. As a result, the relationship of assessment within the courses of a program creates a key element for a successful program.

Huba and Freed's assessment process (Figure 1) is widely used by institutions of higher education across the country. Their model of assessment process has also been applied in a wide variety of programs. A Google search will find hundreds of college and university websites referring to their research on assessment, their assessment process, providing faculty development workshops on assessment, and the development of assessment plans and procedures A few are listed at the end of this paper $[3,4,9,11,12,13]$. 


\section{APPLICATION OF AN ASSESSMENT PROCESS}

Huba and Freed's assessment process was applied to an undergraduate IS program at a midwestern regional university in order to improve assessment measures within individual courses and to better accomplish course goals and program objectives. This institution requires all academic programs to develop unit assessment plans, provide yearly summary reports on assessment activities, and update the plans on a five-year cycle. In addition, the accrediting agency specifies plans that include program reviews and assessment as a part of re-accreditation self-studies.

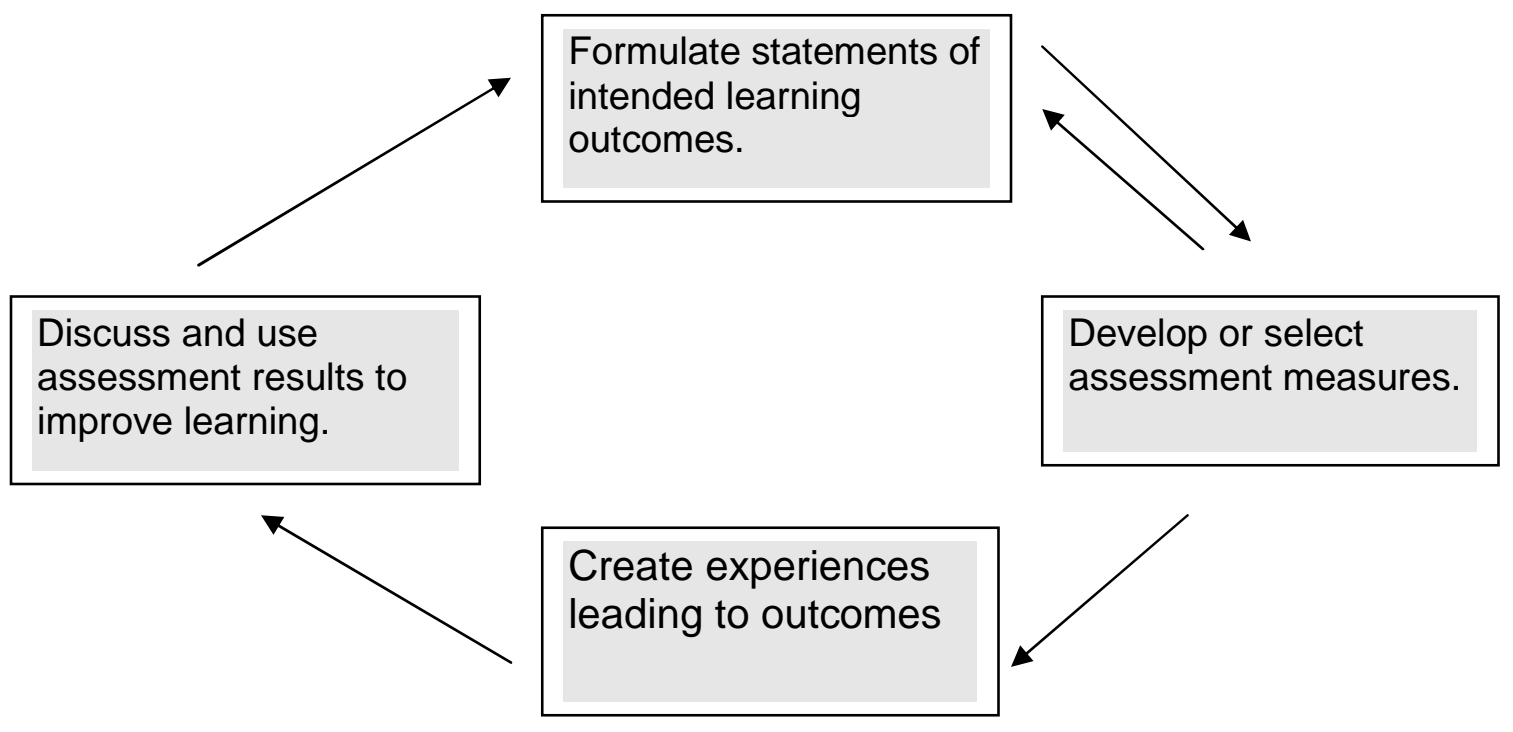

Figure 1. The Assessment Process [5, p. 10]

\section{Step 1: Formulate Statements of Intended Learning Outcomes}

In following the first step of Huba and Freed's assessment process the following ten statements were formulated as the intended student learning outcomes (SLO) for the undergraduate IS program:

1. Explain the systems development process

2. Define a data base architecture using data modeling tools

3. Define a system's processes using process modeling tools

4. Explain transaction processing and the role of Information Systems in supporting transaction processing

5. Demonstrate an ability to use Enterprise software

6. Communicate the importance of computer-supported decision making

7. Communicate the components of network design

8. Demonstrate an ability to work together effectively in a team-oriented environment

9. Effectively communicate in writing and through oral presentations

10. Incorporate socially responsible environmental and ethical considerations into projects/assignment/exams/quizzes 
A curriculum alignment table of the SLOs was also created to show where each SLO is introduced (I), emphasized (E), and/or reinforced (R) in the core courses required in the program.

Table 1. Curriculum Alignment of Student Learning Outcomes with Core Courses

\begin{tabular}{llccc} 
Core Course & \multicolumn{1}{c}{ SLO } & Introduced & Emphasized & Reinforced \\
\hline BIS 228 - Cmptr Prgrm-COBOL & 4 & I & & \\
BIS 247 - SAP Entrprs Sftwr & $3,5,6$ & I & & \\
BIS 247 & 4 & & E & \\
BIS 324 - Vsl Bsc App Dev & 4 & E & & \\
BIS 420 - Sys Anlys\& Dsgn & $1,2,3,8,9,10$ & I & \\
BIS 422 - DB Mgmt Systms & $2,8,9,10$ & I & & \\
BIS 423 - Dcsn Sprt Systms & 6 & I & E & R \\
BIS 423 & $1,8,9,10$ & & &
\end{tabular}

\section{Step 2: Develop or Select Assessment Measures}

Table 2 outlines the primary assessment measures that were developed and/or selected for measuring each SLO of the program. In addition, the year each SLO will be assessed was also identified for this undergraduate IS program.

Course-embedded assessment refers to the use of measures that are already being used in courses by faculty to evaluate their students. For example, the measure used to assess SLO \#2, "define a data base architecture using data modeling tools," is the Entity-Relationship Diagram (ERD) that students are required to draw in their database design course, a senior-level course. Samples of students' ERDs are collected and evaluated by two or more faculty members to determine if these students are achieving the level of learning established by this SLO. This assessment is completed separately from the grading process used by the course instructor [12].

Table 2. Information Systems Program Assessment Matrix

\begin{tabular}{|c|c|c|c|}
\hline $\begin{array}{c}\text { Outcomes } \\
\text { Assessed }\end{array}$ & $\begin{array}{c}\text { Year } \\
\text { Assessed }\end{array}$ & $\begin{array}{l}\text { Primary Assessment } \\
\text { Measures to be Used }\end{array}$ & Expected Measures \\
\hline $1,2,3,4$ & Year 4 & Exit exam & *ISA Certification \\
\hline 5,6 & Year 3 & Course-embedded instruments & $\begin{array}{l}\text { Rubrics for grading } \\
\text { assignments }\end{array}$ \\
\hline 7,8 & Year 4 & $\begin{array}{l}\text { In-class presentations } \\
\text { (videotaped) }\end{array}$ & $\begin{array}{l}\text { Rubrics for in-class } \\
\text { presentations and written } \\
\text { reflection paper }\end{array}$ \\
\hline 9,10 & Year 4 & Course-embedded instruments & $\begin{array}{l}\text { Rubrics and peer faculty } \\
\text { evaluation }\end{array}$ \\
\hline
\end{tabular}




\section{Step 3: Create Experiences Leading to Outcomes}

In addition to the primary assessment measures outlined in Table 2, a wide variety of other assessment measures (both formal and informal) are utilized specifically in the core courses. Research on effective assessment plans and methods was completed and aided faculty in identifying the areas of improvement for creating more effective experiences to achieve the program outcomes.

\section{KEY ELEMENTS OF AN EFFECTIVE ASSESSMENT PLAN}

Key elements and considerations for an effective assessment plan were identified and discussed by faculty. The following goals were established to improve on the assessment measures and learning processes within the program: (i) utilize student self-assessment measures; (ii) utilize non-traditional assessment methods; and (iii) improve solicitation and utilization of feedback from stakeholders (refer to Table 3). Accomplishing these goals will result in activities that will address the three main modes of learning styles_-visual, auditory, and kinesthetic, and provide activities that actively involve students in learning over extended periods of time. As a result of the recent identification of these goals, experiences leading to the desired outcomes for the program are being developed for individual courses on a continual basis $[1,8]$. Some of these elements are explained in the following section.

\section{Student Self-Assessment}

The need to build measures that will require students to be more involved in their own assessment by requiring students to evaluate their own learning was identified as a major goal. Involving students in the assessment and evaluation process is an essential part of a balanced assessment model [9]. Research has shown that student motivation and self-efficacy is increased when they evaluate their own skills and set their own learning goals [11]. "Self-assessment plays a key role in a learner-centered educational environment"[11]. Students will be introduced to the self-assessment process and to program learning outcomes in the core courses.

Utilizing online quiz tools, such as those available in the assessment module of Blackboard Release 6, have been shown to be an effective tool for increasing student retention of course content [11]. Un-graded online quizzes provide immediate, unthreatening feedback and can be used to introduce or reinforce relevant information.

Other measures and activities implemented by faculty include a self-assessment component for presentations. Presentations are videotaped so students can reflect in writing on the effectiveness of a variety of aspects of their presentation, including content, organization, and delivery.

Goal-setting is another self-assessment tool easily applied to any course. At the beginning of a course, students construct a course map based on the course objectives. Students then brainstorm a list of things they want to learn in the course as they relate to the major course objectives. In addition, students can design their own products of learning which allows them to demonstrate learning according to their learning preferences and strengths. 


\section{Non-traditional Assessment Methods}

Especially relevant for IS courses is the need to include non-traditional assessment methods. Traditional assessment methods do not verify performance-based skills. Requiring additional measures of performance-based skills and activities will eliminate an over reliance on traditional assessment techniques and better assess all learners regardless of learning style type.

A non-traditional assessment method used in this IS program is a blog, defined as "a frequent, chronological publication of personal thoughts and Web links" [10]. Blogs are currently a very popular mode of communication to showcase all kinds of issues. Free blogs are easily available and it only takes a few minutes for the students to set one up. Instructors can design a rubric to determine the quality of their students' blogs. At the same time, it is possible to surface the learning that is going on in the class. The blog is basically an electronic journal. As a learning tool, the instructor can use these blogs as a point of discussion in class-writing skills, the need to maintain private information secure and therefore not post them online, the ability to disseminate information to the Internet, and the ability to maintain different personae online.

Another non-traditional assessment method is local, regional, or international competitions such as the annual competition by the Association of Information Technology Professionals (AITP). Students compete with their peers from other universities, demonstrating their IS-related knowledge and skills often tied closely with industry standards and/or applications and developed via relevant IS courses in the program. These competitions also benefit IS faculty. Faculty use these competitions to better tie curriculum to the business world and improve relevancy. Faculty are also able to evaluate the level of success of their students and their degree of preparation attributable to course/program content, classroom activities/assessment.

\section{Step 4: Discuss and Use Assessment Results to Improve Learning}

As the last step of the assessment process, a feedback and assessment results plan was developed that reflects the importance of feedback in achieving SLOs and to provide for continuous improvement within the program. In order to improve the teaching-learning process the assessment model needs to include a means for gathering feedback on program outcomes, including required knowledge, performance-based skills, and the success of our graduates in the workplace. Key to gathering this feedback is to use the information derived from the feedback in a timely manner to make changes and improvements as warranted at the institutional, program, and course levels.

Dissemination of the results to stakeholders, including the program's advisory board (MIS Advisory Board), was also planned in order to stimulate reflection and discussion of the outcomes. As shown in Table 3, the results of the program's exit exam is communicated to a variety of stakeholders, including the advisory board corporate members, students, alumni, companies, and faculty via the Department website, University assessment website, newsletters, and focus group meetings with students. 


\section{CONCLUSIONS}

Assessment as a continuous improvement process for academic programs is a challenging task for faculty. Developing an assessment process that will provide the assessment results and information mandated by a wide variety of constituents within the institution and for agencies outside the institution is a daunting task. However, it is a valuable endeavor since it speaks to the core values of any academic program at any educational institution.

Table 3. Feedback and Assessment Results Plan

\section{Expected Measures from the Instruments \\ Results of exit exam \\ Exit survey of IS grads and/or focus groups}

Course evaluations (midterm and final) and focus groups

Workplace surveys of IS alumni (1-5 years out)
Affected Stakeholders

MIS Advisory Board corporate members, students, alumni, companies, faculty and others

Faculty, MIS Advisory Board corporate members, students, alumni, companies and others

Faculty, students, and MIS Advisory Board corporate members

MIS Advisory Board corporate members, students, alumni, companies, faculty and others

Faculty/students
Methods/Locations for Dissemination of Results

Discussion groups/meetings

Department website University assessment website Reports to faculty/students

Discussion groups/meetings

Department website Reports to faculty/students Relevant publications and/or presentations

Discussion groups/meetings Department meetings Focus group meetings Department newsletter

Department meetings Discussion groups/meetings Department website Relevant publications and/or presentations

In-class discussion

One-minute feedback assessments (informal, inclass feedback method)

Preliminary results of the application of the assessment process for this IS program demonstrates a change in the climate of the department, with three important changes occurring. First, faculty have become more interested in their own professional development. They have also become more focused on the integration of the program learning outcomes with their course assignments. This course of action means that their courses are better designed [14]. These faculty want to become better teachers so that their students will learn more. Second, students are more engaged in their learning as a result of the emphasis on learner-centered instruction. Third, corporate members of the MIS Advisory Board have gained a better understanding of the program and are more supportive of the efforts of the department to connect with them. In addition, many of them 
have expressed their willingness to participate in the assessment efforts of the program. At the same time, changes in the assessment effort will have to continue as faculty learn more about the tools and techniques that can be used to evaluate the learning of their students. The reward will be quality graduates from this IS program—graduates that have abilities beyond the technical skills they learnt in class.

\section{REFERENCES}

1. Angelo, T.A. \& Cross, K. P. (1993). Classroom Assessment Techniques: A Handbook for College Teachers (2nd ed.). San Francisco: Jossey-Bass.

2. Cross, K. P. (1998, July-August). Why learning communities? Why now? About Campus, 411.

3. http://uwadmnweb.uwyo.edu/acadaffairs/assessment/Definitions.htm . Assessment of Student Learning. University of Wyoming. Retrieved 6/29/2005.

4. http://www.roch.edu/dept/asl/ . Assessment of Student Learning. University Center Rochester, located in Rochester, MN, is a higher education partnership between Rochester Community and Technical College, University of Minnesota, and Winona State University. Retrieved 6/29/2005.

5. Huba, M. \& Freed, J. (2000). Learner-Centered Assessment on College Campuses: Shifting the Focus from Teaching to Learning. Boston: Allyn \& Bacon.

6. Muirhead, B. (2002, February). Relevant Assessment Strategies for Online Colleges \& Universities. USDLA Journal. www.usdla.org/html/journal/FEB02_Issue/article04.html. Retrieved 4/27/2005.

7. Pausch, L. M. \& Popp, M. P. (1997). Assessment of Information Literacy: Lessons from the Higher Education Assessment Movement. Association of College \& Research Libraries. www.ala.org/ala/acrlbucket/nashville1997pap/pauschpopp.htm. Retrieved 4/29/2005.

8. Seward, B.L. (2004, June). Formative and Summative Assessment Techniques for Continuous Agricultural Technology Classroom Improvement. NACTA Journal. www.findarticles.com/p/articles/mi_qa4062/is_200406/ai_n9451845/pg_1. Retrieved 2/22/2005.

9. www.eduplace.com/rdg/res/assess/. (1997). Student Self-Assessment. Houghton Mifflin Company. Retrieved 2/18/2005.

10. www.marketingterms.com/dictionary/blog/. Marketing Terms.com. Internet Marketing Reference. Retrieved 4/29/2005.

11. www.usc.edu/isd/locations/cst/tlsnew/emergingthemes/student.html. Theme: Student SelfAssessment. University of Southern California, Teaching and Learning Services, Center for Scholarly Technology. Retrieved 2/18/2005.

12. http://www.provost.wisc.edu/assessment/manual/manual2.html. Theme: Outcomes Assessment. University of Wisconsin System. Retrieved 4/29/2005.

13. www.ncsu.edu/undergrad_affairs/assessment/assess.htm. Office of Assessment. North Carolina State University. Retrieved 6/19/2005.

14. Wiggins, G. \& J. McTighe. (1998). Understanding by design. Alexandria, VA: Association for Supervision and Curriculum Development. 